\title{
КУПИРОВАНИЕ ЭПИЛЕПТИЧЕСКОЙ АКТИВНОСТИ У КРОЛИКОВ С ПОМОЩЬЮ СЕРОТОНИН-МОДУЛИРУЕМОГО АНТИКОНСОЛИДАЦИОННОГО БЕЛКА
}

\author{
Э.Н.Панахова, А.М.Аллахвердиева, А.А.Мехтиева, А.А.Мехтиев * \\ Институт физиологии им. А.И.Караева НАН Азербайджана, Баку.
}

Ключевые слова: эпилептические судороги, натриевая соль пенициллина, амигдала, вызванные потенциалы, серотонин-модулируемый антиконсолидационный белок.

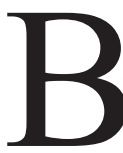

настоящее время многочисленными исследованиями продемонстрирована вовлечённость серотонинергической системы в патогенез эпилепсии. Исследованиями в экспериментальных моделях на животных и клиническими исследованиями выявлено, что эпилепсия развиваетсянафоненизкогоуровнясеротонина в головном мозге [9]. С другой стороны, активация серотонинергической системы оказывает антиконвульсивный эффект. В частности, активация серотонинового рецептора 5-НТ1А вызывает мембранный гиперполяризационный ответ, обусловленный повышенной калиевой проводимостью [4, 12] и оказывает противосудорожный эффект в различных экспериментальных моделях in vivo также, как и на моделях судорог в системе in vitro, включая: гиппокампальные судороги раскачки на кошках; судороги на свободно подвижных крысах, вызванные внутригиппокампальным введениемкаиновой кислоты; судороги на препаратах срезов гиппокампа крыс, вызванные пикротоксином, бикукулином и каиновой кислотой $[7,10,13$, 17].

Одна из экспериментальных моделей, модель генетически предрасположенных к эпилепсии крыс (ГПЭК), проясняет влияние серотонина на чувствительность к судорогам. ГПЭК имеют сниженную плотность рецепторов 5-НТ1А в гиппокампе по сравнению с неэпилептическими контрольными крысами [14]. По сравнению с контролем в большинстве участков конечного мозга и в отдельных участках ствола мозга у ГПЭК отмечалось снижение уровня серотонина, поглощение синпатосомного серотонина и триптофангидроксилазной активности (в системе in vivo и in vitro). Анализ кинетических констант поглощения синаптосомного меченого серотонина и в системе in vitro триптофан гидроксилазной активности показал, что снижение этих параметров, проявленных ГПЭК, в основном, является следствием снижения величины Vmax, a не Km, т.е. количества рецепторов, a не их аффинности. Выявленный факт поддерживает гипотезу о том, что существует широко масштабное снижение количества серотонинергических терминалей в мозге ГПЭК [15]. Кроме того, селективный ингибиторы обратного захвата серотонина (СИОЗС) сертралин создаёт дозо-зависимое снижениеинтенсивностиаудиогенныхсудорог у ГПЭК, коррелирующее с повышенным внеклеточным содержанием серотонина в таламусе головного мозга [18]. В целом, соединения, которые повышают уровень серотонина, такие как 5-гидрокситриптофан и СИОЗС ингибируют как лимбические, так и генерализованные судороги. В протиивоположностьэтому, истощениеуровня серотонина головного мозга уменьшает порог аудиогенных и вызванных химическим и электрическим путём судорог.

*e-mail: arifmekht@yahoo.com 
Принимая во внимание накопленные литературные сведения, авторами была поставлена задача изучения участия нового внутриклеточного серотонин-модулируемого антиконсолидационного белка СМАБ, впервые идентифицированного в коре головного мозга и выделенного из целого головного мозга крыс и находящегося в прямой зависимости от уровня серотонина [2], в формировании эпилептической активности у кроликов, вызванной подведением раствора пенициллина в амигдалу.

Материалы и методы исследований. Выделение СМАБ осуществляли из головного мозга быка (ранее методом твёрдофазного непрямого иммуноферментного анализа (ТНИФА) было выявлено отсутствие видовой специфичности у СМАБ [11]). Головной мозг гомогенизировали в экстрагирующем буфере, содержащем 0,05 М фосфатный буфер ( $\mathrm{pH}$ 7,2), 0,3 M NaCl, 5 мМ ЭДТА и 0,1\%-ный тритон X-100, в объёмном соотношении ткани и буфера 1: 4. Основными этапами фракционирования были: 1) осаждение сульфатом аммония в интервале 0-40\%ного насыщения; 2) гель-хроматография на колонке (3 X 60 см) сефадекса G-150. Процесс фракционирования и отбора иммунопозитивных фракций находился под контролем ТНИФА с применением поликлональных иммуноглобулинов к СМАБ. Гомогенность выделенного белка оценивали методом электрофореза в полиакриламидном геле в трис-глициновой буферной системе (pH 8,3).

Эпилептическую активность индуцировали у бодрствующих кроликов породы Шиншилла весом 2,5-3 кг, зафиксированных в станке, путёмподведениянатриевойсолипенициллина (300 единиц в 10 мкл дистиллированной воды) в амигдалу головного мозга через предварительно вживлённые хемоды. Вживление электродов для регистрации вызванных потенциалов в зрительной коре (ЗК), верхних буграх четверохолмия (ВБЧ) и сетчатке, а также хемодов осуществляли на наркотизированных этаминалом натрия животных (30 мг/кг). Электроретинограмму (ЭРГ) регистрировали с помощью контактной линзы, изготовленной из оргстекла и заполненной физиологическим раствором. В опытной группе животным внутримышечно вводили СМАБ в объёме 3,5 мл и концентрации 1,5 мг/мл в забуференном физиологическом растворе (pH 7,2), контрольным животным физиологический раствор.

Результаты исследований и обсуждение. В результате проведенных исследований было обнаружено, что подведение раствора пенициллина (10 мкл, 300 ед) в амигдалу через 30 мин приводило к резкому облегчению формирования вызванных потенциалов в ЗК и ВБЧ, проявлявшийся в значительном возрастании амплитуд их позитивных компонентов, при этом в сетчатке отмечалось увеличение “c"-волны ЭРГ.

Визуально эпилептический очаг, созданный в амигдале, приводил к формированию продолжительных клонических судорог у животного. Развитие амигдалярной эпилептиформной активности продолжалось в течение 30-40 мин и достигало своего максимума на 50-ой минуте. Следует отметить, что в самой кульминации судорожной активности отмечались значительные модуляции паттерна вызванных потенциалов не только в центральных структурах зрительной системы - ЗК и ВБЧ, но и в её периферическом отделе - в сетчатке. При этом в самой амигдале, ЗК, ВБЧ и сетчатке начинают регистрироваться интериктальные спайки (Рис.1). В контрольной группе животных судороги продолжались более 3 ч. На следующем этапе исследовали влияние СМАБ на гиперактивность нейрональных элементов базолатеральной амигдалы, ЗК, ВБЧ и сетчатки. Было выявлено, что внутримышечное введение СМАБ (3,5 мл; 1,5 мГ/мл) через 30-40 мин приводило к супрессии клонических судорогуживотных. Вструктурах 


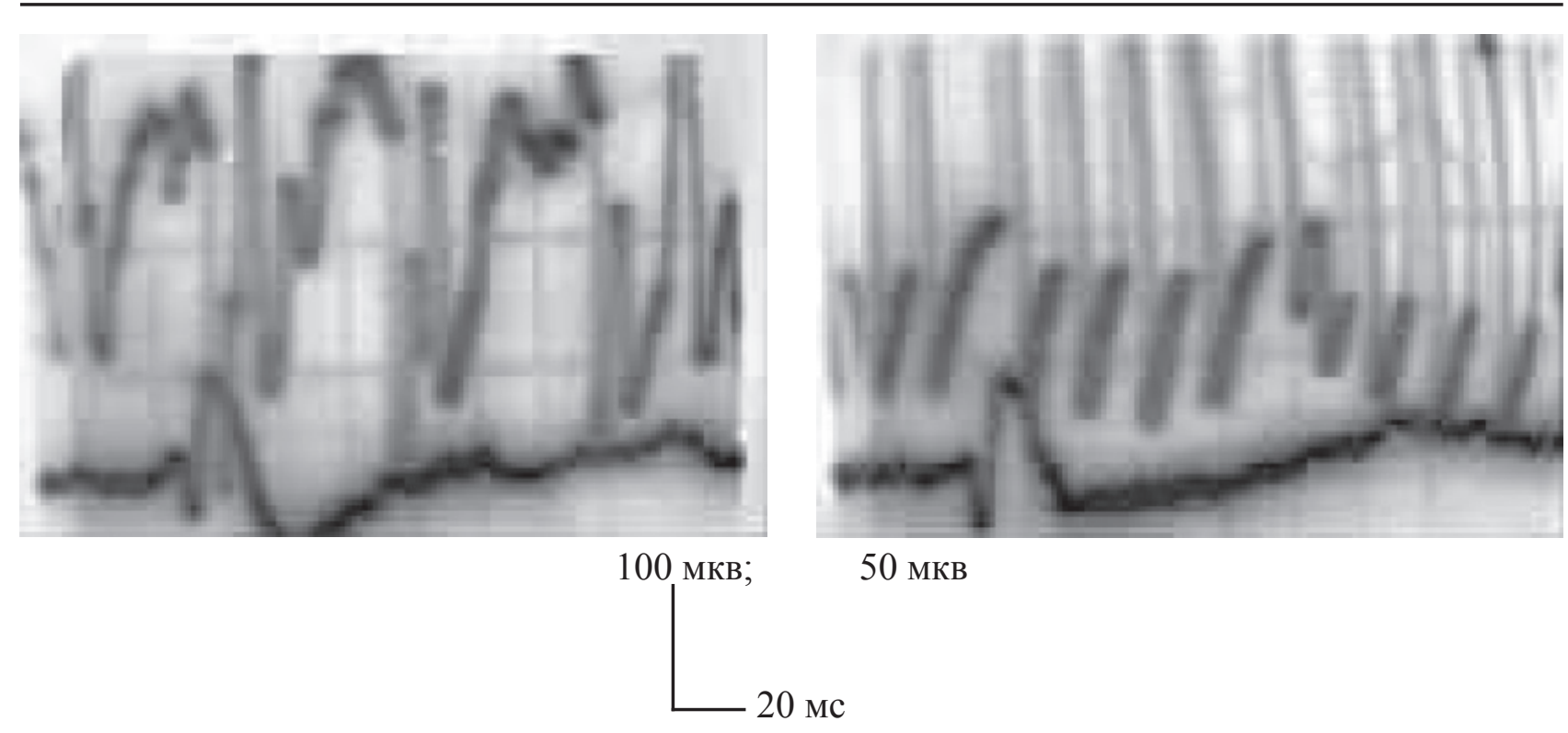

Рисунок 1. Динамика паттернов вызванных потенциалов в зрительной коре и электроретинограммы при введении пенициллина в амигдалу.

головного мозга при этом наблюдалась элиминация интериктальных и иктальных спайков (Рис. 2), однако уровень возбуждения нейронных ансамблей во всех исследованных структурах сохранялся в течение более продолжительного времени. Восстановление исходных параметров вызванных потенциалов происходило в обратном порядке: сначала полное восстановление вызванной активности отмечалось в сетчатке, ВБЧ и ЗК, тогда как в амигдале повышенная возбудимость сохранялась на протяжении более длительного времени.

Представленные результаты показали, что моделирование эпилептического очага в амигдале позволяет выявить распространение возбуждения как в моторных структурах головного мозга (клонические судороги), так и в различных структурах зрительного анализатора. Последнее послужило предпосылкой для изучения обратного эффекта, а именно, влияния эпилептического очага в зрительной зоне коры на активность амигдалы и ВБЧ.

Результаты исследования показали, что в структурах ВБЧ, состоящих из 7 слоёв, в условиях создания пенициллинового фокуса

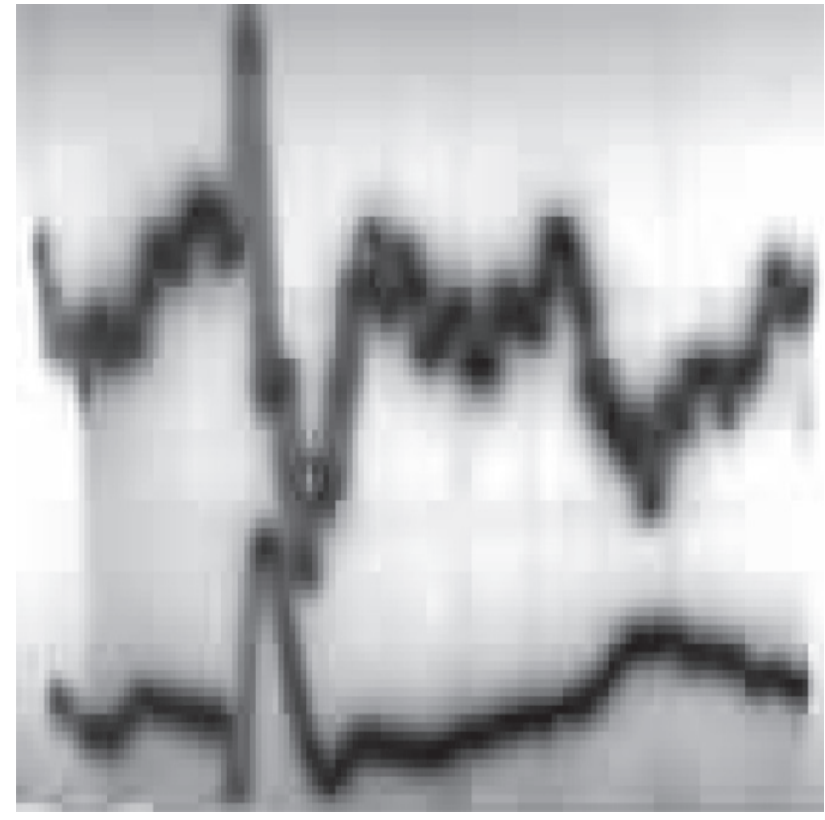

100 мкв; 50 мкв

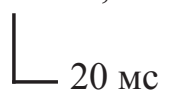

Рисунок 2. Купирование (супрессия) эпилептических пенициллиновых спайков посредством внутримышечного введения СМАБ животным.

эпилептической активности в зрительной коре наблюдается формирование иктальных и интериктальных спайков. Создание очага повышенной возбудимости приводит к 
возникновению эпилептиформных разрядов в 17-ом поле ЗК и сопровождается выраженным усилением активности нейронного аппарата ВБЧ, проявлявшемся в существенном облегчениигенерациивызванныхпотенциалов ВБЧ и модуляции их паттерна.

По-видимому, эффект пенициллинового очага в ЗК при регулярной световой стимуляции проявлялся в качестве киндлинга (раскачка) и, как следствие, приводил к модулированию ответов на свет в ВБЧ. Распространение возбуждения в сторону амигдалы осуществлялось как по прямым [5, 6], т.е. олигосинаптическим путям, так и по проводящим путям через подушку таламуса (pulvinar), ВБЧ и гипоталамические ядра (супрахиазматическое, супраоптическое, вентромедиальное). Каждая из указанных структур имеет прямые и обратные связи с амигдалярным комплексом. Вероятно, нейронные механизмы, отличные от амигдалярного киндлинга, могут принимать участие в формировании кортикального киндлинга с вовлечением в этот процесс такой подкорковой структуры как ВБЧ, имеющей непосредственные связи с моторной (через нижние слои) и зрительной (через верхние слои) системами. Вероятность вовлечения в процесс киндлинга подкорковых и ассоциативных структур зрительной системы (НКТ, ВБЧ и подушка) подтверждается исследованиями [16], которые полагают, что судорожные разряды от затылочной коры распространяются с постепенным вовлечением вышеуказанных структур и появлением в них судорожных разрядов.

Предполагается, что в результате действия пенициллина, приводящего к нарушению ГАМК-ергического торможения, в структурах ноцицептивной системы запускается формирование пароксизмальной эпилептиформной активности - патологической системы, захватывающей и высший корковый уровень. О существовании прямых связей из амигдалы (от крупноклеточной части базального ядра) к 17-му полю зрительной коры свидетельствуют ультраструктурные данные [6], на основании которых авторы показали, что магноцеллюлярные интермедиальные участки базального ядра амигдалы имеют чёткие проекции в поверхностные слои коры (I и II). Входы амигдалярного комплекса влияют, в основном, на пирамидные нейроны в VI слое затылочной коры. На наличие обратных связей ЗК с амигдалой указывают ранние исследования Herzog [8].

Эффекты СМАБ по купированию эпилептической активности обусловлены его серотонин-модулируемой природой, выявленной в биохимических и электрофизиологических исследованиях $[1,2,3]$. Введение СМАБ животным с развившимися эпилептическими судорогами приводит к повышению уровня активности серотонинергической системы на внутриклеточном уровне в клетках головного мозга, блокируя таким образом судорожные разряды.

\section{ЛИТЕРАТУРА}

1. Гасанов Г.Г., Мехтиев А.А. Выявление серотонин-модулируемой белковой фракции и изучение её участия в организации поведения пассивного избегания.//Бюллетень экспер. биол. мед., 1991, Т. 112, № 7, С.5-7.

2.МехтиевА.А.Обнаружениевголовноммозгекрыс белка, обладающего антиконсолидационными свойствами.//Бюллетень экспер. биол. мед., 2000, T. 129, № 8, С. 147-150.
3. Мехтиев А.А., Козырев С.А., Никитин В.П., Шерстнёв В.В. Избирательное влияние антител к белку SMP-69 на активность командных нейронов оборонительногоповедениявиноградныхулиток.// Российский физиол. журнал им. И.М.Сеченова, 2003, T. 89, № 4, C. 389-396.

4. Beck S.G., Choi K.C. 5-Hydroxytryptamine hyperpolarizes CA3 hippocampal pyramidal cells through an increase in potassium conductance.// Neurosci 
Lett., 1991, V.133, p. 93-96.

5. Chen Y, Zhu B, Shou T. Anatomical evidence for the projections from the basal nucleus of the amygdala to the primary visual cortex in the cat.// Neurosci Lett., 2009, V. 453, № 2, pp. 126-30.

6. Freese S.H., Amarel D.G. The organization of projections from the amygdala to the visual cortical areas TE and VI in the macaque monkey.// J.Comp. Neurol., 2005, V. 13, № 486, p. 295-317.

7. Gariboldi M., Tutka P., Samanin R., Vezzani A. Stimulation of 5-HT1A receptors in the dorsal hippocampus and inhibition of limbic seizures induced by kainic acid in rats.// Br. J. Pharmacol.// 1996, V. 119 , p. 813-818.

8. Herzog A.G., Van Hoesen G.W. Temporal neocortical afferent connections to the amygdale in the rhesus monkey.// Brain Res., 1976, V. 115, № 1, pp. 625-629.

9. Jobe P.C. Common pathogenic mechanisms between depression and epilepsy: an experimental perspective.// Epilepsy Behav., 2003, V.4 Suppl. 3, p. S14-24.

10. Lu K.T., Gean P.W. Endogenous serotonin inhibits epileptiform activity in rat hippocampal CA1 neurons via 5-hydroxytryptamine 1A receptor activation.// Neuroscience, 1998, V. 86, p. 729-737.

11. Mekhtiev A.A., Gaisina A.A., Palatnikov G.M., Kasimov R.Yu. Serotonin-modulating protein content as a biomarker of environmental pollution // Soil \& Sediment Contam.: Intern. Journal. 2005. V. 14, № 2, P. 115-121.
12. Okuhara D.Y., Beck S.G. 5-HT1A receptor linked to inward-rectifying potassium current in hippocampal CA3 pyramidal cells.// J Neurophysiol 1994, V. 71, p. 2161-2167.

13. Salgado-Commissariat D., Alkadhi K.A. Serotonin inhibits epileptiform discharge by activation of 5-HT1A receptors in CA1 pyramidal neurons.// Neuropharmacology, 1997, V. 36, p. 1705-1712.

14. Statnick M.A., Dailey J.W., Jobe P.C., Browning R.A. Abnormalities in 5-HT1A and 5-HT1B receptor binding in severe-seizure genetically epilepsy-prone rats (GEPR-9s).// Neuropharmacology, 1996, V. 35, p. 111-118.

15. Statnick M.A., Dailey J.W., Jobe P.C., Browning R.A. Abnormalities in brain-serotonin concentration, high-affinity uptake, and tryptophan-hydroxylase activity in severe seizure genetically epylepsy-prone rats.// Epilepsia, 1996, V. 37, № 4, p. 311-321.

16. Wada Y., Hasegawa H., Okada H., Yacida K., Yamaguchi N. Kindling of the visual cortex in cat: Comparison with amygdaloid kindling.// Jpn. J. Psychiatry Neurol., 1989, V. 43, № 2, pp. 245-253.

17. Wada Y., Nakamura M., Hasegawa H., Yamaguchi N. Role of serotonin receptor subtype in seizures kindled from the feline hippocampus.// Neurosci. Lett., 1992, V.141, p. 21-24.

18. Yan Q.S., Jobe P.C., Dailey J.W. Further evidence of anticonvulsant role for 5-hydroxytryptamine in genetically epilepsy-prone rats.// Br. J. Pharmacol., 1995, V. 115, p. 1314-1318. 


\title{
SEROTONIN-MODULLU ANTIKONSOLIDASIYYA ZÜLALININ VASITTSİ İLO ADA DOVŞANLARINDA EPILEPTIK AKTIVLIYIIN SAKITLOŞDİRILMəSI
}

\author{
E.N.Pənahova, A.M.Allahverdiyeva, A.A.Mehdiyeva, A.Đ.Mehdiyev \\ AMEA-nın A.I. Qarayev adına Fiziologiya İnstitutu, Bakı.
}

\begin{abstract}
Məqalədə epileptik qıcolmaların inkişafinın molekulyar əsasları və serotonin-modullu antikonsolidasiya zülalının (SMAZ) yeridilməsindən serotoninergik aktivliyin hüceyrədaxili səviyyəsində artırılması ilə q1colmaların sakitləşməsinin yeni üsulu əks olunur. Həmin zülal əvvəl siçovulların baş beynindən təmizlənilib, onun molekulyar kütləsi 186 kDa bərabərdir və o, serotonin ilə düz mütanasib əlaqədədir. Epileptik qıcolmalar Şinşilla ada dovşanlarında amiqdalaya natriy penisillin 300 vahidın mikroaplikasiyası vasitəsi ilə yaranıb. Görmə qabığda, yuxarı qabarcığlarda və torlu qişada yaradılmış potensiallar (YP) qeyd olunub. Epileptik qıcolmalar öz zirvəsinə 50 dəqiqəyə çatıb və $3 \mathrm{~s}$ ərzində davam edib. Onların inkişafı zamanı pozitiv komponentlərin artırılması şəklində YP-rın güclənməsi, interiktal spaykların əmələ qəlməsi və zahiri mioklon q1colmalar qeyd olunub. Epileptik qicolmaların yaranmasından 30 dəq sonra ada dovşanlarına SMAZ-ın yeridilməsi (3.5 ml, 1.5 $\mathrm{mq} / \mathrm{ml}$, əzələdaxili) interiktal spaykların daxil olmaqla qicolmaların bütün göstəricilərinin aradan götürülməsi və onların sakitləşməsi ilə nəticələnib. Dəlillərin əsasında belə bir nəticə irəli sürünür ki, SMAZ-ın miqdarının artırılması epileptik qıcolmaların sakitləşməsinə gətirir.
\end{abstract}

Açar sözlər: epileptik qicolmalar, penisillinin natriumlu duzu, amiqdala, törədilən potensiallar, serotoninmodullu antikonsolidasiya zülalı.

\section{SUMMARY}

\section{SUPPRESSION OF EPILEPTIC ACTIVITY IN RABBITS THROUGH SEROTONIN-MODULATING ANTICONSOLIDATION PROTEIN}

\author{
E.N.Panahova, A.M.Allahverdiyeva, A.A.Mekhdiyeva, A.A.Mekhtiev \\ A.I.Karaev Institute of Physiology, NAS of Azerbaijan, Baku
}

The article concerns molecular basis of epileptic seizures development and elaboration of novel ways of their suppression through upregulation of serotonergic system activity on subcellular level by administration of serotonin-modulating anticonsolidation protein (SMAP). This protein had been purified earlier from the rat brains, possesses with $\mathrm{Mr} 186 \mathrm{kDa}$ and is being in linear relationship with serotonin. Epileptic seizures were formed in Shinshilla rabbits by microapplication of 300 units of sodium penicillin solution into the brain amygdala. The evoked potentials (EP) to light flashes were fixed in the visual cortex, colliculus superior and retina. The epileptic seizures reached their peak for $50 \mathrm{~min}$ and lasted for $3 \mathrm{~h}$. During their development, strengthening of the EP in the form of increasing their positive components, advent of interictal spikes and visually myoclonical seizures was observed. Administration of SMAP $(3.5 \mathrm{ml}, 1.5 \mathrm{mg} / \mathrm{ml}, \mathrm{i} . \mathrm{m}$.) to rabbits $30 \mathrm{~min}$ after induction of epileptic seizures led to their suppression and elimination of their all manifestations including interictal spikes. The conclusion is done that upregulation of SMAP leads to suppression of epileptic seizures.

Key words: epileptic seizures, sodium penicillin, amygdale, evoked potentials, serotonin-modulating anticonsolidation protein.

Redaksiyaya daxil olub: 01.11.2011

Çapa tövsiyyə olunub: 26.11.2011

Rəyçi: R.L.Həsənov, t.e.d., dosent 